\title{
CES
}

COOPERATIVISMO E ECONOMÍA SOCIAL

Núm. 40 (2017-2018), páxs. 31-58

ISSN: $1130-2682$

\section{THE NEW LAW ON ENERGY COMMUNITIES IN GREECE}

\author{
IFIGENEIA DOUVITSA*
}

Recepción: 23/09/2018 - Aceptación: 17/10/2018

* Dr. Iur., Adjunct Professor, Hellenic Open University; Teaching Fellow, Democritus University of Thrace, Greece. E-mail: ifigeneiadouvitsa83@yahoo.gr 


\begin{abstract}
Greece has been one of the European countries mostly affected by issues related to energy poverty. In order to address the above phenomenon, a new law was passed on the 17th of January 2018. The central idea of the new law (L. $4513 / 2018$ ) is to introduce a new business model that will facilitate the transition to renewable energy sources with the active participation of local actors, while tackling the pressing issue of energy poverty. The vehicle through which the aforementioned goals will be achieved is a new type of cooperatives, that of the "energy communities" according to the terminology that is used by the legislator. However, several provisions on matters of membership, distribution of surpluses and allocation of the remainder after the energy community's liquidation need a closer examination due to their inconsistency with the cooperative values and principles, as enshrined in the International Cooperative Alliance Statement on the Cooperative Identity.

Therefore, the study aims to offer an analysis of the recent L. 4513/2018 on energy communities. Specifically, it will examine if such initiative was a necessary step for the energy cooperatives' formation and if the added provisions promote their development, without putting in jeopardy the distinctive nature of cooperatives. To address the above questions, the study will base its analysis on the ICA Statement on Cooperative Identity and on the Principles of European Cooperative Law. The study aspires to provide useful information for comparative studies on energy cooperative laws that are interested in including the Greek case and take into account the new law's particular provisions.
\end{abstract}

KEY WORDS: energy cooperatives, energy communities, Greek cooperative law. 
CONTENTS: 1. INTRODUCTION. 2. THE COOPERATIVE LEGAL FRAMEWORK IN GREECE. 2.1. The ar. 12.4 of the Greek Constitution. 2.2. The ordinary cooperative laws. 2.3. The enactment of a new law- L. 4513/2018 on energy communities (EC). 3. CONTENT OF THE LAW. 4. ANALYSIS. 4.1. The necessity of introducing a new law on energy cooperatives. 4.2. Positive elements of the new law. 4.2.1. Reduction of the minimum number of members. 4.2.2. The participation of local authorities as members at an EC. 4.2.3. Other provisions. 4.3. Provisions under question. 4.3.1. The term EC. 4.3.2. The goals and activities of the EC. 4.3.3. Membership requirement. 4.3.4. The distribution of surplus. 4.3.5. Distribution of the remaining funds after dissolution/liquidation. 5. CONCLUSIONS. 6. BIBLIOGRAPHY.

\section{INTRODUCTION}

W ithin the Greek jurisdiction, cooperatives are protected by the Constitution and by the numerous special laws applicable to different types of cooperatives. The lack of a general cooperative law combined with an ever-growing number of special cooperative laws has formed a deeply fragmented legal framework with various consequences in the development of the cooperative movement. The above fragmentation has been aggravated with the financial crisis outburst, when cooperatives went high in the political agenda of the governments that emerged in power since then. Such political interest brought about various legal changes resulting in either amending or abolishing laws on existing cooperative types (e.g. L. 4384/2016 on agricultural cooperatives) or in introducing new cooperative types, such as the enactment of L. 4513/2018 on energy communities (hereafter “ $E C$ ”).

The law on EC was drafted by the Ministry of Environment and Energy, submitted for discussion at the Hellenic Parliament on the 11th of December 2017 and voted by the deputies on the 17th of January $2018^{1}$. The main goals of the law are to enable the transition of the country to a broader use of renewable energy sources, as well as addressing energy poverty related issues through the active participation of citizens, local businesses and local authorities ${ }^{2}$. The aforementioned goals are to be achieved by the development of a new type of cooperatives, that of the "energy communities" according to the terminology that is used by the

\footnotetext{
1 See Hellenic Parliament official site <https://www.hellenicparliament.gr/Nomothetiko-Ergo/Anazitisi-Nomothetikou-Ergou?law_id=24ac2366-281a-488b-97a9-a846014bc8bb>.

2 See Explanatory report of draft law "Energy communities and other provisions", 14th of November 2017, p. 1-2.
} 
legislator ${ }^{3}$. Based on ar. 1 L. 4513/2018, EC are a type of civil cooperative aiming at the energy production, storage, self-consumption, supply and distribution. With the new law, the participation of local authorities is promoted and special clauses have been included for the less populated islands of the country to facilitate the formation of EC in such regions. Nevertheless, a number of specific rules on the requirements for membership, the distribution of surpluses and the allocation of the remainder after the EC's liquidation pose questions on whether they effectively translate into legal rules the cooperative values and principles as stipulated in the International Cooperative Alliance (hereafter "ICA") Statement on the Cooperative Identity ${ }^{4}$.

The study shall focus on the national legal order, for the purpose of examining and reflecting upon the content of the recent L. 4513/2018. Specifically, the necessity of introducing a new law for energy cooperatives shall be investigated, and its provisions will be analyzed regarding whether they promote the energy cooperatives' development, without putting in jeopardy the distinctive nature of cooperatives. For this reason, the study of relevant European energy law rests outside the goals of the present article.

To address the above questions, the study will base its analysis on the ICA Statement on Cooperative Identity and on the Principles of European Cooperative Law (hereafter "PECOL"). The study's findings may offer useful insight to comparative studies on energy cooperative laws that wish to include in their research the Greek case and take into account the new national law's particular provisions.

\section{The COOPERATIVE LEGAL FRAMEWORK IN GREECE}

\subsection{The ar. 12.4 of the Greek Constitution ${ }^{5}$}

According to a recent study, approximately one out of three national constitutions in the world explicitly refers to cooperatives in their provisions ${ }^{6}$. The Greek

\footnotetext{
3 See Explanatory report of draft law "Energy communities and other provisions", $14^{\text {th }}$ of November 2017, p. 1-2.

4 See International Cooperative Alliance official site <https://www.ica.coop/en/whats-co-op/cooperative-identity-values-principles>.

5 In ar. 12.5 the Greek Constitution refers to mandatory cooperatives, the participation in which is compulsory and thus they shall not be discussed in this study.

${ }^{6} 62$ national constitutions out of the 180 that have been under study explicitly refer to cooperatives. For the above findings see DOUVITSA, I., «National constitutions and cooperatives. An overview», International Journal of Cooperative Law 1(2018), p. 131: "The study found that the countries that have introduced cooperative articles in their constitutions are in Africa: Angola, Central Africa, Congo, Egypt, Equatorial Guinea, Ethiopia, Guinea-Bissau, Kenya, Morocco, Mozambique, Namibia, Nigeria, Sao Tome and Principe, Swaziland (Table 1); in Asia: Bangladesh, China, Cyprus, India, Iran, Korea (DPR), Kuwait, Malaysia, Myanmar, Nepal, Pakistan, Philippines, Sri Lanka, Taiwan,
} 
Constitution is one of them, which in ar. 12.4 designates that "the agricultural and civil cooperatives ${ }^{7}$ of any kind are self-governed according to the laws and their by-laws, protected and supervised by the state, which is responsible for their development". The above article is applicable to all types of cooperatives, including the EC under study and establishes two cooperative rights. In particular, all cooperatives enjoy the social right for state protection, according to which the state may introduce supporting measures for their growth ${ }^{8}$. The above provision also stipulates the civil right of the cooperatives for autonomy and self-governance, as long as it is exerted in consistency with the laws, their by-laws and state supervi$\operatorname{sion}^{9}$. Based on the latter the ordinary legislator may introduce general provisions and conditions for cooperatives' establishment, organization and function, without however intervening in the cooperative administration and function ${ }^{10}$. Nevertheless, in the past there had been noted major interferences by governments in the cooperatives' affairs, encouraged by highly detailed and overregulated laws in detriment of the cooperatives' autonomy, self-governance and eventually selfgrowth $^{11}$.

\subsection{The ordinary cooperative laws}

The Greek legal landscape on cooperatives consists of L. 4430/2016 ${ }^{12}$, which is a general legal framework on social and solidarity economy, and a plethora

Tajikistan, Timor-Leste, Thailand, Turkey, Uzbekistan, Yemen (Table 2); in the Americas: Bolivia, Brazil, Colombia, Costa-Rica, Cuba, Dominican Republic, Ecuador, El Salvador, Guatemala, Guyana, Haiti, Honduras, Mexico, Nicaragua, Panama, Paraguay, Peru, Suriname, Uruguay, Venezuela (Table 3) and in Europe: Belarus, Bulgaria, Greece, Italy, Malta, Portugal, Serbia, Spain (Table 4). Compared to Africa (14/54, 26\%) and Asia (20/48, 41\%), South America has the highest rate (20/35, 57\%), whereas Europe the lowest (8/43, 19\%)".

7 The Greek legislator distinguishes two general categories of cooperatives: the agricultural cooperatives with farmers as their members (where L. 4384/2016 is applicable) and all the rest are considered as civil cooperatives (where L. 1667/1986 applies as the framework law on civil cooperatives). See KINTIS, S., Cooperative Law (in Greek), Athens, Ant. N. Sakkoulas, 2004, p. 56.

8 MAVROGIANNIS, D., The Social Right of Cooperatives, in Five Years of Implementation of the Constitution of 1975 (in Greek), Komotini, DUTH, 1981, 1981, 37-96; DAGTOGLOU, P., Constitutional Law - Civil rights, Athens, Ant. N. Sakkoulas, 2005, p. 903; XRYSOGONOS, K., Civil and Social Rights (in Greek), Athens, Nomiki Vivliothiki, 2006, p. 507.

9 DAGTOGLOU, P., Constitutional Law - Civil rights, Athens, Ant. N. Sakkoulas, 2005, p. 902; XRYSOGONOS, K., Civil and Social Rights (in Greek), Athens, Nomiki Vivliothiki, 2006, p. 507.

${ }^{10}$ KINTIS, S., Cooperative Law (in Greek), Athens, Ant. N. Sakkoulas, 2004, p. 69.

${ }^{11}$ KLIMI-KAMINARI, O., The relations between state and cooperatives in Greece for the development of the agricultural population (in Greek), Athens, Panteion University of Social and Political Sciences, 2003, p. 79, 100.

${ }^{12}$ The L. 4430/2016 on social and solidarity economy in ar. 1-13 introduces provisions applicable to all social solidarity economy actors, in which cooperatives may be included as long as they fulfill the conditions laid down in ar. 3 (except for social cooperative enterprises, limited liability social coop- 
IFIGENEIA DOUVITSA

of specific laws applied to different cooperative types. In principle, cooperatives are divided into two broad categories based on the activity that they undertake, which are on the one hand the agricultural cooperatives and on the other the civil cooperatives $^{13}$. Specifically, L. 4384/2016 regulates the agricultural cooperatives, as well as women's agricultural cooperatives, whereas L. 1667/1986 on civil cooperatives stipulates general rules for all cooperatives that are active outside the agricultural sector. For particular sub-types of civil cooperatives, special laws are applicable along with the complementary implementation of L. 1667/1986. Indicatively, such sub-types are the banking cooperatives, the limited liability social cooperatives, the social cooperative enterprises, the worker cooperatives and the energy cooperatives. The special law on energy cooperatives (or "energy соттиnities" according to the legislator's terminology), is considered to be the thus far newest addition to the gamut of cooperative-specific laws.

\subsection{The enactment of a new law- L. 4513/2018 on energy communities (EC)}

The Ministry of Environment and Energy drafted a new law on EC, which was voted by the majority of the deputies on the $17^{\text {th }}$ of January 2018 . According to its explanatory report, the enacted law took into account the Proposal for a directive of the European Parliament and of the Council on the promotion of the use of energy from renewable sources $(\mathrm{COM}(2016) 767)$ and the Proposal for a directive of the European Parliament and of the Council on common rules for the internal market in electricity (COM (2016) 864).

By passing a new law, the Ministry aspired to address the energy poverty, a phenomenon that seemed to have escalated, since the financial turmoil of 2008. According to a broadly used definition, energy poverty is described as the situation when "a person or household is not able to heat or fuel their home to an acceptable standard at an affordable cost ${ }^{14 "}$ ". A more specific definition states that " $a$ household is in fuel poverty if in order to maintain a satisfactory heating regime, it would be required to spend more than 10\% of its income on all household fuel $u s e^{15 "}$. Recent findings on the above defined phenomenon indicated that a considerable percentage of the population is energy deprived in Greece. In particular, in

eratives and worker cooperatives that are acknowledged as de lege social solidarity economy actors). Then, in ar. 14-23, the L. 4430/2016 prescribes for the social cooperative enterprises, and in ar. 24-33 for worker cooperatives.

${ }^{13}$ KINTIS, S., Cooperative Law (in Greek), Athens, Ant. N. Sakkoulas, 2004, p. 56.

${ }^{14}$ JONES, S., Social causes and consequences of energy poverty, in Csiba, K., Bajomi, A., Gosztonyi, A., Energy poverty handbook, Brussels, European Union, 2016, p. 21-22.

15 JONES, S., Social causes and consequences of energy poverty, in Csiba, K., Bajomi, A., Gosztonyi, A., Energy poverty handbook, Brussels, European Union, 2016, p. 21-22. 
$201230 \%$ of total population was unable to keep their home adequately warm, $78.6 \%$ admitted to using less heating than needed, due to the fact that they could not afford it and $62.4 \%$ of the population spends more than $10 \%$ of their total income for heating ${ }^{16}$. The fact that the population's incomes have been diminished by $30 \%$, along with the price volatility and high energy costs are considered to be decisive factors preventing the needs in energy consumption of the population to be properly covered, especially for the vulnerable groups of the population, which have been most affected ${ }^{17}$. Furthermore, the poor thermal efficiency and housing in Greece and in particular the average energy consumption of buildings which is higher compared to other countries with more severe winter conditions, such as Germany and Denmark, ${ }^{18}$ are additional drivers that preserve and further aggravate the energy poverty phenomenon.

Additionally, the law aims at enabling the country's transition to green energy. To this end the legislator promotes the citizens, municipalities and local businesses to be actively engaged in the country's energy transition and energy planning. Regarding the island region of the country, the law considers that a considerable number of islands especially in the Aegean Sea are not connected to the mainland's infrastructure. Therefore, they tend to heavily rely on fossil fuels and during peak season the costs in energy consumption are soaring. Hence, the law sets as a goal to facilitate the island regions' energy autonomy based on renewable energy sources, by prescribing special clauses for them ${ }^{19}$.

The main vehicle to achieve the above goals is the introduction of a new type of cooperatives, that of the energy cooperatives (or "energy communities" according to the terminology that is used by the legislator).

${ }^{16}$ THOMSON, HR, SNELL, C.J., «Quantifying the prevalence of fuel poverty across the European Union», Energy policy 52 (2013), p. 563-572; PANAS, E., Research on energy poverty in Greece in Greek, Department of Statistics, Athens University of Economics and Business, 2012; ATANASIOU, B., KONTONASIOU, E., MARIOTTINI, F., Alleviating fuel poverty in the EU: Investing in home renovation, a sustainable and inclusive solution, Buildings Performance Institute Europe (BPIE), 2014, p. 32.

${ }^{17}$ PANAS, E., Research on energy poverty in Greece in Greek, Department of Statistics, Athens University of Economics and Business, 2012. See also SANTAMOURIS, M., PARAVANTIS, JA., FOUNDA, D., «Financial crisis and energy consumption: a household survey in Greece», Energy and Buildings 65 (2013), p. 477-487.

${ }^{18}$ The average energy consumption of buildings in Greece is $29 \mathrm{kWh} / \mathrm{m}^{3}$ per year, whereas in Germany it is $21 \mathrm{kWh} / \mathrm{m}^{3}$ per year and in Denmark $13 \mathrm{kWh} / \mathrm{m}^{3}$ per year. See PANAS, E., Research on energy poverty in Greece in Greek, Department of Statistics, Athens University of Economics and Business, 2012.

${ }^{19}$ Explanatory report of draft law "Energy communities and other provisions", $14^{\text {th }}$ of November 2017, p. 1-2. 
IFIGENEIA DOUVITSA

\section{CONTENT OF THE LAW}

The law 4513/2018 on energy communities is divided into two sections, the first of which consists of ar. 1-12, and refers to energy communities, adding to the body of the cooperative law proper, while the second section consists of ar. 13-32 reforming provisions of energy laws. This study shall focus its analysis on the first part of the law and in particular on its most crucial provisions concerning the formation, function and dissolution of an EC.

The law uses the terminology "energy community", instead of "energy cooperative", being influenced by the European directive on renewable energy communities $^{20}$, while avoiding at the same time the "cooperative" term due to a preexisting negative public image of agricultural cooperatives in Greece that led to a generalized misconception on the cooperative model of business ${ }^{21}$.

\footnotetext{
${ }^{20}$ See ar. 22 of the Proposal for a directive of the European parliament and of the council on the promotion of the use of energy from renewable sources COM (2016) 767 final: "Renewable energy communities: 1. Member States shall ensure that renewable energy communities are entitled to generate, consume, store and sell renewable energy, including through power purchase agreements, without being subject to disproportionate procedures and charges that are not cost-reflective. For the purposes of this Directive, a renewable energy community shall be an SME or a not for-profit organisation, the shareholders or members of which cooperate in the generation, distribution, storage or supply of energy from renewable sources, fulfilling at least four out of the following criteria: (a) shareholders or members are natural persons, local authorities, including municipalities, or SMEs operating in the fields or renewable energy; (b) at least $51 \%$ of the shareholders or members with voting rights of the entity are natural persons; (c) at least $51 \%$ of the shares or participation rights of the entity are owned by local members, i.e. representatives of local public and local private socio-economic interests or citizen having a direct interest in the community activity and its impacts; (d) at least $51 \%$ of the seats in the board of directors or managing bodies of the entity are reserved to local members, i.e. representatives of local public and local private socioeconomic interests or citizens having a direct interest in the community activity and its impacts; (e) the community has not installed more than 18 $M W$ of renewable capacity for electricity, heating and cooling and transport as a yearly average in the previous 5 year. 2. Without prejudice to State aid rules, when designing support schemes, Member States shall take into account the specificities of renewable energy communities". See also FAJARDO, G., The European legal framework, does it promote renewable energy self-consumption cooperatives?, International Cooperative Alliance (ICA) European Research Conference "Cooperatives in a rapidly changing world: Innovation in Enterprise and Community", 4 July 2018 until Fri 6 July 2018, Wageningen, Netherlands. See also MEIRA, D., Legal obstacles to the creation of renewable energy communities under cooperative form in Portugal: Coopernico as a case study, International Cooperative Alliance (ICA) European Research Conference "Cooperatives in a rapidly changing world: Innovation in Enterprise and Community", 4 July 2018 until Fri 6 July 2018, Wageningen, Netherlands, according to which cooperative is the legal form, best fitted for the concept of renewable energy community.

${ }^{21}$ AVDELIDIS, P., The agricultural cooperative movement in Greece (in Greek), $2^{\text {nd }}$ ed., Athens, Papazisi Editions, 1976, p. 60-61; See PATRONIS, V., MAVREAS, K., «Agricultural cooperative organizations in Greece throughout the $20^{\text {th }}$ Century: A Critical Overview», Journal of Rural Cooperation 32 (2004), p. 51-62, 53; ILIOPOULOS, C., VALENTINOV, V., «Opportunism in Agricultural Cooperatives in Greece». Agriculture 41 (2012), p. 15-19, 16; MAVROGIANNIS, D. Sociology of Law Courses: University lectures (in Greek), Athens, Sakkoulas, 1980, p. 139-140; KASSAVETIS, D., Cooperative Institutions I. Agricultural Cooperative Organizations (in Greek), Athens, Katsarou,
} 
The legislator, when defining the EC, takes into account the division of cooperatives into the agricultural cooperatives, which undertake agricultural activities and civil cooperatives, in which all non-agricultural cooperatives are included ${ }^{22}$. The EC are designated by law as a particular type of civil cooperatives. The civil cooperatives according to ar. $1 \mathrm{~L} .1667 / 1986$ "are voluntary unions of persons with an economic goal, aiming - especially through the collaboration of their members- at the economic, social, cultural development of their members and the betterment of their standards of living in a join enterprise, without however undertaking activities in the sector of agriculture". For any matter that the law on EC has not introduced relevant provisions, the law on civil cooperatives is applicable.

The legislator chooses to place the EC in the civil cooperatives' category, specifying, however the exclusive goals that they may pursue. The above goals are stipulated by law which include -among else- the production, distribution and supply of energy, the promotion of energy self-sufficiency and security in island municipalities, the undertake of activities at the renewable energy sources or the co-production of electricity and high efficiency heat (ar. 1.1 L. 4513/2018).

Based on the above, the EC may not pursue any kind of goals, but only the ones that the law stipulates, in which agriculture is exempted (ar. 1.1 L. 4513/2018 and ar. 1.1 L. 1667/1986). The latter is in line with ar. 4 L. 4513/2018 that describes the activities that an EC can undertake. In ar. 4 par. 1 the above law introduces a list of mandatory activities, at least one of which the EC has to exert. Such mandatory activities mainly refer to the provision of energy related services, products and infrastructure development, such as - among others - : the production, the storage, the self-consumption or selling of electric or thermal or cooling energy, the management (such as collection, transport, processing, storage or distribution) of the raw materials for the production of electricity or heat or cooling energy from biomass or bioliquid or biogas or through the energy exploitation of the biodegradable municipal waste fraction, supplying its members with electrically operated vehicles or vehicles using alternative motor fuels. Apart from the mandatory activities, the law 4513/2018 in ar. 4 par. 2 includes also a list of optional activities, such as attracting capital to be invested within the district of its headquarters, managing or participating at funding programs relevant to its goals, raising awareness on energy sustainability issues, undertaking initiatives in supporting consumers of vulnerable groups and addressing energy poverty irrespectively if the persons in need are members or non members (for instance by energy supplying or offsetting, or by energy housing upgrading or other actions

2005, p. 62; DOUVITSA, I. «Supervision and audit of the Greek agricultural cooperatives: A critical approach on legislation», European Business Law Review 29 (2018), p. 77 ff.

${ }^{22}$ KINTIS, S., Cooperative Law (in Greek), Athens, Ant. N. Sakkoulas, 2004, p. 56. 
that reduce the energy consumption). From the optional list, the EC may choose freely to exercise one or more such activities, as long as it exerts at least one mandatory activity of ar. 4 par. 1L. 4513/2018. Apart from the aforementioned mandatory and optional activities of par. 1 and par. 2 of ar. 4 , no further activities shall be exerted by an EC (ar. 4.2 L. 4513/2018).

Furthermore, the law on EC introduces specific provisions on membership. In general, physical persons, legal persons of private law and legal persons of public law, including the local authorities, can become members of an EC. Ar. 2 par $2 \mathrm{~L}$. 4513/2018 stipulates that the EC can be formed with five, three or two members depending on their membership basis and the area of their headquarters and it states as follows:

\begin{abstract}
"The minimum number of members of an EC is: a) five in case the members are public law legal entities, except for local authorities, or private law entities or individuals, b) three in case the members are legal persons of public or private law or physical persons, as long as two at least are local authorities, c) two in case the members are only local authorities of first tier of island regions of the country with less than 3.100 habitants according to the latest census".
\end{abstract}

The above provision implies that a five-member EC can be established between private law legal persons, individuals and public law legal persons, in which local authorities are exempted. The latter does not prohibit the local authority from participating at the EC, but its participation shall not contribute to the fulfillment of the five-member requirement- thus it shall join for instance as the sixth member. In the following two cases ( $b$ and $c$ ), the legislator's intent to facilitate the formation of an EC by the local authorities results in requiring the lowest possible membership, especially in less populated island regions of the country. In particular, in the $\mathrm{b}$ case, a three-member EC can be legally formulated with two local authorities as members and a third member that can be either a public or private law legal person or an individual. In the exceptional case of scarcely populated islands, even a two-member EC is possible as long as both members are local authorities of first tier. The aforementioned minimum number of members shall sign the by-laws, so that the EC can be legally formed. The process is held in front of the district court according to ar.1.3 L 1667/1086 on civil cooperatives, which applies also to EC.

The EC is bound by law to comply with the above requirements not only during its formation, but for all its lifespan, otherwise their non-fulfillment constitutes a reason for the EC dissolution (ar.9.1a L. 4513/2018).

Furthermore, the law on EC prescribes a set of locality criteria in ar. 2.3 for the EC membership to promote the EC as locally rooted enterprises. In particular, 
$51 \%$ of the EC members are expected to have local ties with the district within which the EC has its headquarters. In case of members-individuals these ties shall be demonstrated by a) ownership rights or b) by the right to use (usufruct) of immovable property within the district of EC, or c) by being residents of the area (which requires them to be officially registered in that particular municipality). Similar provisions apply to the legal entities-members of the EC, which in order to demonstrate the above local ties their headquarters are required to be within the district that the EC has its headquarters. These local ties are a requirement for the majority $(51 \%)$ of the overall number of members, whereas the $49 \%$ of the EC members is not obliged to fulfill such criteria (ar. 9.1a L.4513/2018). The locality criteria of ar. 2.3 L. 4513/2018, as it was the case with the abovementioned membership requirements, shall be met during and after the EC formation, the lack of which establishes grounds for their dissolution (9.1a L. 4513/2018).

When it comes to the EC capital formation, ar. 3 L. 4513/2018 provides that the members shall contribute to the cooperative capital with a mandatory cooperative share, but they can also acquire one or more voluntary cooperative shares, which, nonetheless, cannot surpass the $20 \%$ of the total cooperative capital. The above cap is higher reaching up to the $40 \%$ of the total cooperative capital when the local authorities acquire such voluntary shares and in case of first tier local authorities of islands with less than 3.100 habitants, the above percentage rises to $50 \%$ of the cooperative capital. Irrespectively, however, of the shares that each member contributes to the EC, it is acknowledged one vote (ar.3.2 L. 4513/2018).

Regarding the surplus distribution, ar. 6 L. 4513/2018 applies, which uses the term surplus in order to describe the economic outcome of the year, including thus not only the surpluses that have been acquired from the transactions of the cooperative with its members, but also profits that originate when the cooperative transacts with non-members. Moreover, the legislation in the above article lays down two different systems for surplus distribution resulting in implicitly dividing the EC into two categories, the not-for-profit and the for-profit EC, without however using such wording. A common denomination for both categories is the requirement of allocating at least $10 \%$ of the surplus to the legal reserve of the EC, whether it is not-for-profit or for-profit and this is the only commonality between the two emerging EC types. In particular, according to the first system of distribution which depicts the not-for-profit EC, the rest of the surplus is prohibited from being distributed to members. Instead, it is allocated to other reserves based on the general assembly's decision aiming at promoting the EC goals. For the EC which consists of local authorities only, as well as the EC in which local authorities participate as members in island regions with less than 3.100 habitants, the surpluses - party or totally - may be allocated for local collective activities associated with the energy sector, such as the supply of raw materials, fuels and water. On the other hand, the second distribution system, that renders EC as for -profit desig- 
nates that the rest of the surplus (after the 10\% deduction for the legal reserve), can be distributed to members as long as the EC consists of at least 15 members (or 10 members in island regions with less than 3.100 habitants) and $51 \%$ of the members are physical and not legal persons. The above ratio of physical persons' membership that is the majority of the EC members is to be met during and after the EC formation.

The EC are able to form EC unions and a Hellenic federation of energy communities, based on ar. 10 L. 4513/2018. The unions consist of at least five members- EC located within the same district and aim at the coordination and promotion of their members' activities. Since such activities are not defined by law, it may be argued that economic as well as advocacy activities can be included, which shall be further specified by the cooperators themselves. The above unions may also form a Hellenic federation of energy communities for the coordination and the overall representation of the whole national energy cooperative movement. With respect to a minimum number of such unions- members to form the federation, the law remains silent. In the case of the Hellenic federation, the activities are those that respond to the advocacy and lobbying needs of the movement. Both the unions and the federation take the cooperative form and are subjected to the complementary application of relevant articles of L. 1667/1986 on civil cooperatives concerning their cooperative vertical integration.

The dissolution of the EC is also a topic of great interest stipulated by law. According to ar. 9 L. 4513/2018, an EC can be dissolved if the required number of members or the locality criteria are not fulfilled anymore and the appropriate adjustments do not occur within a three-month period. Additionally, dissolution can also occur for an EC in case in its by-laws a specific duration is stated, which expires or after a general assembly decision. The bankruptcy of the EC is also a reason for its dissolution.

With the EC dissolution, liquidation follows. After the members' cooperative shares are redeemed, the distribution of the remainder depends on the way in which the surpluses have been distributed within the cooperative. For those EC that are subject to the non-distribution provision (the not-for-profit EC), the remainder shall not be allocated to the members, but to associations, unions or other non-profit entities, which undertake activities within the district of EC on the energy sector or on the environmental protection. On the other hand, the EC that have distributed their surpluses to their members (for-profit EC) shall, accordingly do so after the cooperative's liquidation by distributing the rest of the funds to the members according to their contributions to the cooperative capital. 


\section{ANALYSIS}

\subsection{The necessity of introducing a new law on energy cooperatives}

The first question that is posed about the new law is whether such legislative initiative was necessary for the formation and operation of cooperatives in the energy sector and renewable energy; or instead, if the new law shall be added to the already complex and fragmented cooperative legal landscape in Greece. The fact that energy cooperatives, even in short numbers, were formed under L. 1667/86 as civil cooperatives or under L. 4430/2016 as social cooperative enterprises ${ }^{23}$, prior to the new law, indicates that its passing was not a conditio sine qua non for their establishment. In the current context, an energy cooperative may be established under L. 1667/1986 on civil cooperatives, or according to L. 4430/2016 on social and solidarity economy which prescribes for the formation of social cooperative enterprises and worker cooperatives or based on L 4513/2018 on EC. The above result in having three different organizational cooperative laws that overlap, under which energy cooperatives may be formed, despite the fact that these cooperatives operate within the same sector. The issue of overregulation that emerges in the cooperatives under study is a rather broader phenomenon affecting various sectors of the social and economic life in Greece. In the case of cooperatives in particular, it took in the past excessive forms reaching 946 reforms of the first cooperative law between 1915 and 1970, in other words two reforms per month, whereas from 1984 to1994, 230 agricultural cooperative laws had been passed ${ }^{24}$. Although, overregulation has been mainly spotted in the agricultural cooperative sector, since the financial crisis of 2008 , it has re-emerged as a trend ${ }^{25}$ expanding to other sectors, as well ${ }^{26}$. The latter reflects the extensive role that the state still

${ }^{23}$ Indicatively, the "Sifnos island cooperative" was formed in 2013 as a civil cooperative in the island of Sifnos. See Sifnos island cooperative official site $<$ https://www.sifnosislandcoop. gr/en/index.html $>$. The Energy cooperative company of Karditsa was also formed as a civil cooperative in Karditsa in 2010. See BELLIS, V., The case of the Energy cooperative company of Karditsa, Korinthos Chambers, 18th of February 2018; Iliokaliergia was formed as a social cooperative enterprise of collective and social benefit in Kalamata in 2017. See Ministry of Labour official site (Social and solidarity economy General Registry, 28/6/2018) available at <http://www.ypakp. gr/index.php?ID=UQH3HmYOtWvx5Eoq\&Rec_ $\mathrm{ID}=12229>$.

${ }^{24}$ LAMBROPOULOU-DEMETRIADOU, B., Assessment of the Greek Cooperative Legislation, in Papageorgiou, K., (ed.), An Assessment of Greek Cooperative Institutions (in Greek), Athens, Institute of Cooperation, 1995, p. 87-99, 90-91.

${ }^{25}$ The previous law 4015/2011 on agricultural cooperatives has been amended ten times in a four-year period until its recent abolishment by L. 4384/2016 in April 2016. See DOUVITSA, I. «Supervision and audit of the Greek agricultural cooperatives: A critical approach on legislation», European Business Law Review 29 (2018), p. 79-80.

${ }^{26}$ For instance, a new law (L. 4423/2016) was passed specifically for forest cooperatives, which were previously subjected to the agricultural cooperative law. Moreover, the recent law on social and solidar- 
holds in the social and economic life, which under the polarized political system usually fails to reach to a broader consensus resulting in numerous and short-lived legal rules affected by the changes in the political sphere ${ }^{27}$.

\subsection{Positive elements of the new law}

\subsubsection{Reduction of the minimum number of members}

The question on whether the new law was necessary for the energy cooperatives' development remains open. Nevertheless, such remark should not overshadow the positive features that were introduced by L. 4513/2018. In particular, the new law divergences from the fifteen-member requirement of the formation of civil cooperatives by lowering the minimum number of members between two and five ${ }^{28}$. The fact that the Greek legislator follows the general tendency of national legislators to reduce the minimum membership on cooperatives may be considered as a progress, especially since augmenting the number of members has failed to bring about positive results in Greece ${ }^{29}{ }^{30}$. The new law's provision is also in line with the nature of cooperatives as voluntary organizations, the participation in which should be the product of free will based on the freedom of as-

ity economy introduced provisions on worker cooperatives, which were previously formed under L. $1667 / 1986$ and on collective and social benefit and integration social cooperative enterprises, the latter overlapping to some extent with the social cooperatives of ar. 12 of L. 2716/1999. Most recently, a draft law on a new type of social cooperative enterprises is under discussion by the Ministry of Health.

${ }^{27}$ SOTIROPOULOS, D., CHRISTOPOULOS, L., Overregulation and bad quality laws in Greece, Athens, Dianeosis, 2017, p. 15-16.

${ }^{28}$ However, an energy cooperative as a social cooperative enterprise of social and collective benefit can be formed with five members (ar. 14 L. 443/2016).

${ }^{29}$ On average in European jurisdictions the minimum number of members is three. FAJARDO, G., FICI, A., HENRŸ, H., HIEZ, D., MEIRA, M., MUNKNER, HH., SNAITH, I., Principles of European Cooperative Law. Principles, Commentaries and National Reports, Cambridge, Intersentia, 2017, p. 39.

${ }^{30}$ HENRŸ, H., Finland, in: Fajardo, G., Fici, A., Henrÿ, H., Hiez, D., Meira, M., Munkner, HH., Snaith, I., Principles of European Cooperative Law. Principles, Commentaries and National Reports, Cambridge, Intersentia, 2017, p. 147; MUNKNER, HH., Germany, in: Cracogna, D., Fici, A., Henrÿ, H. (eds), International handbook of cooperative law, Heidelberg, Springer, 2013, p. 418; SNAITH, I. (2013). United Kingdom, in: Cracogna, D., Fici, A., Henrÿ H. (eds), International handbook of cooperative law, Heidelberg, Springer, p. 744; FAJARDO GARCIA, I. G., Spain in: Cracogna, D., Fici, A., Henrÿ (eds), H. International handbook of cooperative law, Heidelberg, Springer, 2013, p. 709; MEIRA, D., Portugal, in: Fajardo, G., Fici, A., Henrÿ, H., Hiez, D., Meira, M., Munkner, HH., Snaith, I., Principles of European Cooperative Law. Principles, Commentaries and National Reports, Cambridge, Intersentia, 2017, p. 416; FJØRTOFT, T., GJEMS-ONSTAD, O, Norway and Scandinavian countries, in: Cracogna, D., Fici, A., Henrÿ, H. (eds), International handbook of cooperative law, Heidelberg, Springer, 2013, p. 569. 
sociation, allowing cooperation to emerge in both small and large numbers ${ }^{31}$. The prerequisite of minimum membership should not be used as a tool to pressure the formation of cooperatives of a specific size, but, instead, to introduce a number, below which cooperation is undoubtedly non-functional. According to PECOL sec. 1.3 (4): "a cooperative shall always comprise no fewer than two cooperator members [...]", since collaboration cannot occur with only one person-member ${ }^{32}$. Based on the above, the new law seems to pace in the right direction abstaining from treating cooperatives significantly differently from companies regarding the required number of members ${ }^{33}$.

\subsubsection{The participation of local authorities as members at an EC}

Prior to L. 4513/2018 on EC, the participation of local authorities in energy cooperatives was either forbidden or contested ${ }^{34}$. The above issue has been solved by the explicit reference of L. 4513/2018 on the involvement of local authorities which is not only permitted, but encouraged by the various clauses that the law introduces.

The new law by permitting in ar. 2 the local authorities to form or join an EC reflects the open-door principle of cooperatives, which promotes the inclusiveness of cooperatives to all persons, not only physical but also legal, as long as they are able to use their service. Notably, the local authorities' participation is particularly crucial in the EC case, due to the nature of energy as a common good and the financial and social capital that they can invest in the cooperative.

${ }^{31}$ KLIMI-KAMINARI, O., PAPAGEORGIOU, K., Social economy: A first approach (in Greek), Athens, Ellinoekdotiki, 2010, p. 64.

${ }^{32}$ However, the finish law permits the formation of a one-member cooperative. See. HENRŸ, H., Finland, in: FAJARDO, G., FICI, A., HENRŸ, H., HIEZ, D., MEIRA, M., MUNKNER, HH., SNAITH, I., Principles of European Cooperative Law. Principles, Commentaries and National Reports, Cambridge, Intersentia, 2017, p. 147.

${ }^{33}$ According to ar. 1.3 L. 2190/1920 an anonymous society can be formed by one or more shareholders.

${ }^{34}$ If the energy cooperatives are formed as social cooperative enterprises of social and collective benefit, then local authorities are prevented from becoming their members according to ar. 14.5 L. 4430/2016. The only exception that L 4430/2016 introduces is for social cooperative enterprises for integration, in which the local authorities are permitted to join as members. In the case of energy cooperatives formed as civil cooperatives under L. 1667/1986, such participation is not prevented by the above law, which allows for the participation of legal entities in general as long as the cooperative's by-laws introduces relevant provisions. Nevertheless, in the case of the energy cooperative company of Karditsa, which was formed as a civil cooperative according to the provisions of L. 1667/1986, the decision of Karditsa's municipalities to join the cooperatives was denied by their public authorities' directorate. The latter based its rejection on L. 3852/2010, which in ar. 107.2 prevented the public authorities from forming or participating at anonymous societies except for those explicitly referred to in the law. A possible conclusion may be that cooperatives were wrongly viewed as a type of anonymous society and not as a differentiated form of business. 


\subsubsection{Other provisions}

Another trait of the new law that had a positive reaction was the introduction of special clauses for the less populated island regions, as well as the optional activity of EC to undertake measures in favor of vulnerable groups of the population and address the energy poverty. Such provision implements the 7 th cooperative principle, to care for the community by undertaking activities and measures that the cooperative members decide for their community as a whole or for specific population groups.

\subsection{Provisions under question}

\subsubsection{The term EC}

Some remarks can be made on the term "energy community" that is used by the new law, instead of "energy cooperative". Although, it may reflect the terminology used in the European directive on the renewable energy communities ${ }^{35}$, it is added to the already vast variety of cooperative terms in the Greek legal texts (e.g. agricultural cooperatives, civil cooperatives, limited liability social cooperatives, social cooperative enterprises of social and collective benefit and of integration). However, this is the first attempt to introduce a new terminology without any reference to the cooperative term. The latter may be significant not only for academic reasons, but for practical ones as well, since it is going to be used as the company name in the transactions of the enterprise with the public and the other interested parties. Thus, the choice of the legislator may not only suffer from clarity creating confusion on the enterprise's identity, but also indirectly and even involuntarily, confirms and preserves the negative connotation of the term, due to previous past experiences occurring in the agricultural cooperative sector. If we also take into account the fact that in Greece there has been a long ongoing battle for the use of "cooperative, coop" by a non-cooperative enterprise, which has the exclusive rights for its use in its company name ${ }^{36}$, then it may be concluded that the new law paces in the wrong direction, instead of further protecting and promoting the cooperative title in all mediums.

Apart from the latter, the term cooperative would have been preferred, since it is the one used in the ICA Statement and the International Labour Organization Recommendation 193 of 2002 on Promotion of cooperatives (hereafter " $\mathrm{R}$ $193 / 2002$ "). It is also worth noting that under PECOL the term cooperative enjoys

\footnotetext{
${ }^{35}$ See ar.22 of the Proposal for a directive of the European parliament and of the council on the promotion of the use of energy from renewable sources COM (2016) 767 final.

${ }^{36}$ DOUVITSA, I. The provisions on the company name of cooperatives according to cooperative legislation- in Greek, Editors' Newspaper, 30th of July 2018
} 
a status of protection. Specifically, sec 1.1(5) PECOL stipulates that: "cooperatives shall include in their registered name the word "cooperative", "coop", or similar. The words "cooperative", "coop", or similar, may not be included in the name of entities not formed and managed as cooperatives in accordance with cooperative law and universally recognized cooperative values and principles".

\subsubsection{The goals and activities of the EC}

Another issue to be examined is the exhaustive list of energy-related goals and activities that the new law stipulates for the EC, without allowing any further additions in their by-laws. The latter prevents multiple activities to be exerted by the EC, except those within the energy sector. Although such issue may not rise in the early stages of the EC development, as the EC may grow in numbers and size through time, it prohibits them from expanding their business in other sectors ${ }^{37}$, such as for instance in agriculture. Furthermore, if existing energy cooperatives, which were formed prior to the enactment of the new law, are interested in being converted into an EC, then they are obliged to terminate any additional activities that they have undertaken outside the energy sector, re-adjusting their by-laws accordingly. This occurs due to the fact that the L.1667/1986 on civil cooperatives and the L. 4430/2016 on social solidarity economy, under which energy cooperatives may be formed, do not specify in an exhaustive manner the activities cooperatives in general may undertake, in contrast to the law on EC.

Such restrictions do not comply with the nature of cooperative law prescribed by R.193/2002 as supporting cooperatives' development and in particular recognizing cooperatives operating in all sectors of the economy (sec I (1) R. 193/2002) ${ }^{38}$. Likewise, sec. 1.1 (1) PECOL states that cooperatives are legal persons governed by private law that carry on any economic activity [..]. Therefore, in principle cooperatives should be permitted to be active in any sector of the economy according to the principle of equal treatment ${ }^{39}$, as with anonymous societies.

\footnotetext{
${ }^{37}$ International Labour Office (ILO), Cooperatives Unit (ENT/ COOP), Green Jobs Program., Providing clean energy and energy access through cooperatives, Geneva, ILO, 2013, p. 5: "energy cooperatives can move from single-purpose to multiple approaches". See also HENRŸ, H., Guidelines for Cooperative Legislation, $3^{\text {rd }}$ ed., Geneva, International Labour Organization, 2012, p. 18.

${ }^{38}$ The lack or failure of appropriate mechanisms to safeguard undertaking activities in specific sectors

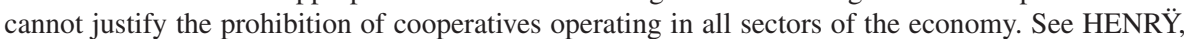
H., Public International Cooperative Law, in Cracogna, D., Fici, A., Henrÿ, H. (eds), International handbook of cooperative law, Heidelberg, Springer, 2013, p. 77.

${ }^{39}$ FAJARDO, G., FICI, A., HENRŸ, H., HIEZ, D., MEIRA, M., MUNKNER, HH., SNAITH, I., PRINCIPLES of European Cooperative Law. Principles, Commentaries and National Reports, Cambridge, Intersentia, 2017, p. 32.
} 


\subsubsection{Membership requirement}

Regarding the membership basis, the fact that both physical and legal persons can adhere to an EC is in line with the internationally accepted definition of cooperatives. In particular, a cooperative is defined as "an association of persons", by the term "persons" including physical and legal persons ${ }^{40}$.

Furthermore, ar. 2.3 L. 4513/2018 prescribes for the majority of the EC members to be - if individuals - owners or usufractuaries of immovable property or officially registered residents within the EC district and - if legal persons- having their headquarters within that district. The above locality criteria create further conditions for an EC formation and impede the growth of its membership base. Such strict and detailed requirements are expected to omit various potential members, such as house renters, unregistered residents and legal entities that have their branch office or store, and not their headquarters, within the EC district ${ }^{41}$.

The restrictions on membership of the new law raise questions on their compliance with the open-door principle. According to the first principle of voluntary and open membership, "cooperatives are voluntary organisations, open to all persons able to use their services and willing to accept the responsibilities of membership, without gender, social, racial, political or religious discrimination". The above principle prescribes for the open door principle under two conditions: a) the ability of the potential members to use their cooperatives' services and b) the acceptance of their responsibilities. The ability to use the cooperatives' services depends on the type of cooperative, for example farmers shall be able to use an agricultural cooperative's services. In that manner, when defining the members' qualification, the law needs to take into account what kind of cooperative shall be subjected to its rules: for instance, in case of producer cooperatives, membership shall be open to producers, in consumer cooperatives to consumers and in multi-stakeholder cooperatives to various groups of stakeholders ${ }^{42}$. Regarding energy cooperatives, however, the legislator's task is harder, since such cooperatives appear in different forms, for instance as producer, consumer or even as multistakeholder cooperatives ${ }^{43}$. Hence, member qualifications in energy cooperatives

\footnotetext{
${ }^{40}$ HENRŸ, H., Guidelines for Cooperative Legislation, $3^{\text {rd }}$ ed., Geneva, International Labour Organization, 2012, p. 71: "cooperatives may be composed of physical persons only, of legal persons only or of a mix of the two".

${ }^{41}$ See Public Consultation Report for the draft law "energy communities and other provisions", July 2017, Hellenic Democracy, Ministry of Environment and energy, p. 43-90 (63-64 comment by Xenophon Zisis).

${ }^{42}$ FAJARDO, G., FICI, A., HENRŸ, H., HIEZ, D., MEIRA, M., MUNKNER, HH., SNAITH, I., Principles of European Cooperative Law. Principles, Commentaries and National Reports, Cambridge, Intersentia, 2017, p. 50-51.

${ }^{43}$ International Labour Organization. Cooperatives Unit. (2013). Providing clean energy and energy access through cooperatives, p. 5 .
} 
should be defined by general and abstract rules, without limiting their potential variations. Under the current article, the law conditions the participation to EC under specific rules of locality. Although in the energy sector locality plays a great role in the provision of services, the legislator should have been discouraged from predetermining that locals and local business shall be the main members able to benefit from the EC services. On the contrary, it would have been preferable for the law not to impose, but encourage locality criteria to be introduced in the EC by-laws, allowing nevertheless exceptions to be made in the EC by-laws. The latter would not only be consistent with the open- door principle as stated in ICA and prescribed in $\mathrm{PECOL}^{44}$, but it would also strengthen the constitutionally established self-governance of the cooperatives in ar. 12.4.

\subsubsection{The distribution of surplus}

Certain aspects of the financial structure of the EC, as prescribed by law, present particularities that need further examination. As stipulated in the law, an EC with less than 15 members, the majority of which are legal and not physical persons (the alleged not-for-profit EC) allocates its surpluses, after the legal reserve deduction, to indivisible reserves (ar. 6 L. 4513/2018). The EC that consists of local authorities only, (or the EC in which local authorities participate as members in island regions with less than 3.100 habitants), may allocate their surpluses party or totally-to local collective activities associated with the energy sector, such as the supply of raw materials, fuels and water (ar. 6.3 L. 4513/2018). On the other hand, the EC with 15 members at least (or 10 members at least in island regions with less than 3.100 habitants), the majority of which are physical and not legal persons, may allocate the rest of their surpluses to their members (the alleged forprofit EC) (ar. 6.4 L. 4513/2018).

A first remark on the above provision refers to the terminology used in the legal text. In particular, the law uses the term "surpluses" to describe all economic results without differentiating those gained from transactions with members and non-members. The latter would not raise issues for any other private company. In the case of cooperatives, however, it is crucial to distinguish the cooperative surpluses (acquired from the cooperative transactions with members), from profits (acquired from transactions between the cooperative and non-members),

\footnotetext{
${ }^{44}$ Sec 1.3 (6) PECOL: "Cooperative statutes may make membership subject to reasonable conditions related to their particular type or objective, without gender, social, ethnic, racial, political or religious discrimination or artificial restriction of membership".
} 
since they are to be allocated in a different manner ${ }^{45,46}$. In the following analysis the term surplus shall be used as a general term describing all economic results, whereas the cooperative surpluses and profits are used with the abovementioned specific meaning.

Moreover, a question is posed on the way the surplus is allocated in the EC and whether the new law's provisions are consistent with the cooperative identity, values and principles. In general, as with every business enterprise, the financial structure is closely associated with the goals that are set to be achieved by that enterprise. For instance, the financial structure of investor-owned companies permits and further promotes the profit accumulation and distribution to their shareholders. Accordingly, the financial structure of cooperatives should enable cooperatives to achieve their distinct purpose, in other words to cover the economic, social and cultural needs of their members through their participation at the cooperative $^{47}$. For this reason, the financial structure of the cooperatives is expected to reflect the cooperative identity, values and principles ${ }^{48}$. Specifically, according to the 3rd cooperative principle"[...] members allocate surpluses for any or all of the following purposes: developing their cooperative, possibly by setting up reserves, part of which at least would be indivisible; benefiting members in proportion to their transactions with the cooperative; and supporting other activities approved by the membership". PECOL further specifies in sec. 3.6(3) that "by resolution of the members'meeting, the cooperative surplus may be: (a) distribute to the cooperator members as cooperative refunds in proportion to the quantity and/or quality of their participation in cooperative transactions, either cash or by shares or other financial instruments, or (b) between indivisible reserves and divisible reserves", whereas in sec.1.5(5) PECOL foresees that the profits from nonmember cooperative transactions are allocated to indivisible reserves. The above

\footnotetext{
${ }^{45}$ HENRŸ, H., Guidelines for Cooperative Legislation, $3^{\text {rd }}$ ed., Geneva, International Labour Organization, 2012, p. 35: "According to the strict cooperative principles, profit will be transferred to an indivisible reserve fund; surplus should be distributed among the members, at least in part, in proportion to their transactions with the cooperative over a specified period of time".

${ }^{46}$ See sec 3.6(1) and 3.7 of PECOL; KINTIS, S., Cooperative Law (in Greek), Athens, Ant. N. Sakkoulas, 2004, p. 39. HENRŸ, H., Guidelines for Cooperative Legislation, $3^{\text {rd }}$ ed., Geneva, International Labour Organization, 2012, p. 94. See also International Cooperative Alliance, Guidance notes to the co-operative principles, 2015, p. 40: "In the co-operative business world we talk of co-operatives making "a surplus" rather than "a profit"». See also KAMINARI, O., PAPAGEORGIOU, K., «The concept of surpluses, profits and net income in cooperatives in Greek», Social Economy, April's Volume, Athens, Institute for Cooperative Studies, 2016.

${ }^{47}$ FAJARDO, G., FICI, A., HENRŸ, H., HIEZ, D., MEIRA, M., MUNKNER, HH., SNAITH, I., Principles of European Cooperative Law. Principles, Commentaries and National Reports, Cambridge, Intersentia, 2017, p. 73-74.

${ }^{48}$ FAJARDO, G., FICI, A., HENRŸ, H., HIEZ, D., MEIRA, M., MUNKNER, HH., SNAITH, I., Principles of European Cooperative Law. Principles, Commentaries and National Reports, Cambridge, Intersentia, 2017, p. 73-74.
} 
provisions define all the possible ways the cooperatives can use their surpluses without putting in jeopardy their distinct identity. How the surpluses are distributed is to be decided by the general assembly according to sec. 3.6(3) $\mathrm{PECOL}^{49}$, as cooperatives are self-governed businesses. The law may introduce, however, some minimum requirements to safeguard the social function of cooperatives as well as their financial stability ${ }^{50}$, such as by prescribing for a percentage of annual results to be allocated at an indivisible legal or educational reserve ${ }^{51}$.

Based on the above, it is noted that for the not-for-profit EC the new law introduces rather strict rules. In particular, it imposes all surpluses to be distributed to indivisible reserves, which deprives them from returning even a small part of their surpluses as patronage refunds to their members based on their cooperative transactions, as the 3rd cooperative principle states and PECOL further highlights. Although the indivisibility of reserves may strengthen the cooperatives' financial structure, which is particularly important in the energy sector, as it is a capitalintensive area of business, the latter does not justify the absolute abolishment of patronage refunds. Such refunds are considered as a way of awarding members for using the cooperative's services, while enabling a price re-adjustment, so that the provided services could be offered near $\cos ^{52}$. Therefore, the decision on how to balance the need for indivisible reserves or/and patronage refunds should have been left to the cooperative as an issue of their internal affairs and strategic planning and not have been decided by the legislator a priori under mandatory rules. The latter is not only implied in 3rd cooperative principle and stipulated in PECOL, but it is also in line with the constitutionally acknowledged principle of cooperatives' self-governance foreseen in ar. 12.4 of the Greek Constitution.

On the contrary, this is not the case for the for-profit EC which are permitted by law to distribute their overall surplus to their members after the legal reserve

\footnotetext{
${ }^{49}$ See also International Cooperative Alliance, Guidance notes to the co-operative principles, 2015, p. 33: "Whilst being always mindful of the long-term viability of their co-operative, members have the right and the duty, collectively, to decide how surpluses should be allocated".

${ }^{50}$ FAJARDO, G., FICI, A., HENRŸ, H., HIEZ, D., MEIRA, M., MUNKNER, HH., SNAITH, I., Principles of European Cooperative Law. Principles, Commentaries and National Reports, Cambridge, Intersentia, 2017, p. 90-91

${ }^{51}$ The Italian and Portuguese law dictates that a percentage of the cooperatives' surplus shall be allocated to an educational and training fund ( ar. 58.1 of the Spanish Cooperative Act n. 27/1999; ar. 97.2 Portuguese Cooperative Code).See FAJARDO, G., FICI, A., HENRŸ, H., HIEZ, D., MEIRA, M., MUNKNER, HH., SNAITH, I., Principles of European Cooperative Law. Principles, Commentaries and National Reports, Cambridge, Intersentia, 2017, p. 91.

${ }^{52}$ FAJARDO, G., FICI, A., HENRŸ, H., HIEZ, D., MEIRA, M., MUNKNER, HH., SNAITH, I., Principles of European Cooperative Law. Principles, Commentaries and National Reports, Cambridge, Intersentia, 2017, p. 90. See also HENRŸ, H., Guidelines for Cooperative Legislation, $3^{\text {rd }}$ ed., Geneva, International Labour Organization, 2012, p. 94. International Cooperative Alliance, Guidance notes to the co-operative principles, 2015, p. 41.
} 
deduction without laying down the specific criteria for such distribution (ar. 6.4 L. 4513/2018). Based on the above provision, on the one hand profits from noncooperative transactions may be allocated to the members, blurring thus the line between cooperatives and investor-owned companies that are active in the energy sector, if in both cases profits gained from the provided services are distributed to members. In fact, it seems unjustifiable why the legislator gives the legal form of a cooperative to an EC that is profit-oriented. On the other hand, surpluses that originate from cooperative transaction may be distributed to the members. Since the legislator remains silent of the criteria for such allocation, the for-profit EC are not prevented from introducing financial criteria (e.g. cooperative shares), contrary to the $3^{\text {rd }}$ cooperative principle. Therefore, it is noted that for these EC the new law introduces rules flexible, yet inconsistent with the 3rd cooperative principle and the overall mutual purpose of cooperatives to cover their member needs and not to allocate the gained profits, as their ultimate goal ${ }^{53}$.

Interestingly, the law deems reserves indivisible or divisible (which leads to their division between not-for-profit and for-profit EC) based on the number of members of the EC and the ratio between legal and physical persons. As mentioned previously, for the EC with less than 15 members and more legal than physical persons the overall remainder of surpluses is by law allocated to indivisible reserves (ar.6.2 L.4513/2018), whereas for EC with more than 15 members and more physical than legal persons the remainder may be returned to members (ar.6.4 L.4513/2018). The number of members and whether they are legal or physical persons does not seem to be a crucial factor to determine the indivisibility of cooperative reserves. The advantage of indivisible reserves is that they may address the general - to all cooperatives - need to counterbalance the variable share capital, to strengthen their long-term viability and to protect it from speculative behavior that can occur by either legal entities or individuals ${ }^{54}$. The latter issues are present to almost all cooperatives, independent of their membership size or ratio between legal and physical persons. Thus, the abovementioned criteria are not considered appropriate to justify whether the reserves may be indivisible or divisible.

\footnotetext{
${ }^{53}$ See also Public Consultation Report for the draft law "energy communities and other provisions", July 2017, Hellenic Democracy, Ministry of Environment and energy, p. 43-90 (64-65 comment by Xenophon Zisis, member of energy social cooperative and by Proskalo).

${ }^{54}$ FAJARDO, G., FICI, A., HENRŸ, H., HIEZ, D., MEIRA, M., MUNKNER, HH., SNAITH, I., Principles of European Cooperative Law. Principles, Commentaries and National Reports, Cambridge, Intersentia, 2017, p. 84. See also ROELANTS, B. Capital building in industrial and service cooperatives, in: The capital conundrum for cooperatives, 2016, International Co-operative Alliance, pp. 22-31 (29-30). See International Cooperative Alliance, Guidance notes to the co-operative principles, 2015, p. 41-42.
} 


\subsubsection{Distribution of the remaining funds after dissolution/liquidation}

A similar approach has been also taken in the new law concerning the funds remaining after liquidation, the distribution of which is not uniformly regulated for all EC. In particular, for the not-for-profit EC the remainder shall not be allocated to the members, but to associations, unions or other non-profit entities which undertake activities within the district of EC on the energy sector or on the environmental protection (ar. 9.2 L. 4513/2018). The latter provision is in line with the principle of disinterested distribution, emanating from the 3rd cooperative principle and stipulated in sec. 3.8 (2) PECOL ${ }^{55}$.

Interestingly, the legislator refers to the non-profit sector as a potential beneficiary of the EC remaining funds, without, however including either other EC or cooperatives from different sectors or stipulating for the creation of a solidarity fund for the creation of new ECs or cooperatives, in general. From the above, it is noted that the value of solidarity, pursued not only among EC themselves, but also between different types of cooperatives, is missing from the legal text and despite how central it is for their cooperative identity it has not been translated into legal rules ${ }^{56}$.

On the other hand, the for-profit EC, with at least 15 members, the majority of which are physical persons, can distribute the remaining of the funds after liquidation to their members based on their contributions to the cooperative capital (ar.9.2 L. 4513/2018). How can then the cooperative be safeguarded against speculative behavior ${ }^{57}$, if the only guarantees the law offers refer to the number and presence of physical persons, which are equally capable with legal persons of dissolving the EC for personal gain? Even if such behavior does not occur, distributing the remainder according to the members' contributions introduces elements of investor-owned companies, promoting the ongoing isomorphism of cooperatives with them ${ }^{58}$.

\footnotetext{
${ }^{55}$ sec. 3.8 (2) PECOL: "Residual net assets shall be distributed in accordance with the principle of disinterested distribution". See FAJARDO, G., FICI, A., HENRŸ, H., HIEZ, D., MEIRA, M., MUNKNER, HH., SNAITH, I., Principles of European Cooperative Law. Principles, Commentaries and National Reports, Cambridge, Intersentia, 2017, p. 94.

${ }^{56}$ In France for instance the residual net asset is to be assigned to another cooperative or to a social solidarity economy enterprise (ar. 19 French Cooperation Act n. 47-1775 of the 10 September 1947). See FAJARDO, G., FICI, A., HENRŸ, H., HIEZ, D., MEIRA, M., MUNKNER, HH., SNAITH, I., Principles of European Cooperative Law. Principles, Commentaries and National Reports, Cambridge, Intersentia, 2017, p. 94.

${ }^{57}$ HENRŸ, H., Guidelines for Cooperative Legislation, $3^{\text {rd }}$ ed., Geneva, International Labour Organization, 2012, p. 99.

${ }^{58}$ HENRŸ, H., Guidelines for Cooperative Legislation, $3^{\text {rd }}$ ed., Geneva, International Labour Organization, 2012, p. 10-13.
} 
In the light of the above remarks it is concluded that the allocation of surpluses in both $\mathrm{EC}$ types is rather problematic before and after the EC dissolution/liquidation, since the distinctive financial structure of cooperatives and in particular the different function of surpluses and profits in the cooperative is not being taken properly into account.

A general remark based on the provisions that were analyzed previously is that the legislator seems to polarize the institution of the EC by dividing it into the notfor-profit and for-profit EC. The former resembles in some of their attributed traits the general interest cooperatives ${ }^{59}$ pursuing mainly the common good of the community under the absolute clause of reserves' indivisibility ${ }^{60}$ and the latter EC are closely associated with the investor-owned model of enterprise aimed at allocating all the surpluses as well as their remainder after dissolution/liquidation to their members. On the other hand, the EC functioning as a cooperative with a mutual purpose, providing part of its surpluses as patronage refunds to its members based on their cooperative transactions and in the event of its dissolution allocating the remainder to other cooperatives is not established under the rules of L. 4513/2018.

\section{Conclusions}

The Greek legal framework on cooperatives mainly consists of the constitutional provision of ar. $12.4^{61}$, the law on SSE and a considerable number of cooperative specific laws applicable to different cooperative types. A recently added law to the already fragmented cooperative legal landscape is L. 4513/2018, enacted on the 17th of January 2018. According to its explanatory report, it aims at addressing the - escalated by the financial crisis of 2008- phenomenon of energy poverty, while enabling the country's transition to green energy through the active participation of the citizens, municipalities and local businesses ${ }^{62}$. It has also taken into consideration the need of the island regions of the country for energy autonomy based on renewable energy sources, by prescribing special clauses for them $^{63}$. In order for the above goals to be achieved, a new type of cooperatives,

\footnotetext{
${ }^{59}$ According to sec 1.1 (5) PECOL general interest cooperatives are defined as cooperatives established to carry on an economic activity mainly in the general interest of the community.

${ }^{60}$ In Portugal, for instance, ar. 7 of the Portuguese Cooperative Code prohibits the distribution of surpluses to members of social solidarity cooperatives. See MEIRA, D., Portugal, in: Fajardo, G., Fici, A., Henrÿ, H., Hiez, D., Meira, M., Munkner, HH., Snaith, I., Principles of European Cooperative Law. Principles, Commentaries and National Reports, Cambridge, Intersentia, 2017, p. 28

${ }^{61}$ In ar. 12.5 the Greek Constitution refers to mandatory cooperatives, the participation in which is compulsory and thus they may not be perceived as authentic cooperatives.

${ }^{62}$ See Explanatory report of draft law "Energy communities and other provisions", $14^{\text {th }}$ of November 2017, p. 1-2.

${ }^{63}$ See Explanatory report of draft law "Energy communities and other provisions", $14^{\text {th }}$ of November 2017, p. 1-2.
} 
that of the energy cooperatives (or "energy communities" according to the terminology that is used by the legislator) is introduced. However, the latter law was not a prerequisite for their establishment, since energy cooperatives, even in short numbers, were established prior to its enactment under L. 1667/86 on civil cooperatives or under L. 4430/2016 on social solidarity economy. As a result, there are three overlapping organizational cooperative laws, under which energy cooperatives can be formed. These are the law on civil cooperatives 1667/1986, the L. 4430/2016 on social solidarity economy that prescribes for social cooperative enterprises and worker cooperatives and the newly passed law on EC 4513/2018.

Even though L. 4513/2018 was not a necessary step for the establishment of cooperatives in the energy sector, it nevertheless introduces a number of positive features with its provisions. In particular, the new law divergences from the 15-member requirement of the civil cooperatives by lowering the minimum number of members between 2 and 5. Furthermore, it encourages the participation of local authorities in EC, resolving in this manner previous concerns on whether local authorities could participate in an energy cooperative as members. Other positively received traits of the new law were the special clauses for the less populated islands facilitating the establishment of EC in such regions, as well as prescribing as an optional activity for the EC to undertake measures in favor of vulnerable groups of the population.

On the other hand, several provisions raise some concerns. In particular, the legislator by using the term "energy community", instead of energy cooperatives, seems to confirm and preserve the preexisting negative connotation of the cooperative term in Greece. In fact, to the author's knowledge this is the first time a law prescribes for cooperatives without even using the specific term of cooperatives as their legal denomination. Such issue may not only create confusion as to the identity of the enterprise, but also paces in the opposite direction by neglecting to protect the name of the cooperative in all mediums, which is needed since there is an ongoing legal battle for the use of the cooperative title by a non-cooperative enterprise.

Furthermore, the exhaustive list of energy-related goals and activities of the EC prevents them from expanding their business in other sectors, such as for instance in agriculture. Such limitations seem to be inconsistent with the nature of cooperative law prescribed by R. 193/2002 as supporting cooperatives' development and in particular recognizing that cooperatives operate in all sectors of the economy which is stipulated in sec I (1)R. 193/2002) ${ }^{64}$ and further stated in sec. 1.1 (1) PECOL.

${ }^{64}$ See HENRŸ, H., Public International Cooperative Law, in Cracogna, D., Fici, A., Henrÿ, H. (eds), International handbook of cooperative law, Heidelberg, Springer, 2013, p. 77, according to which it is noted that the lack or failure of appropriate mechanisms to safeguard undertaking activities in specific sectors cannot justify the prohibition of cooperatives operating in all sectors of the economy. 
Moreover, the locality criteria introduced by the new law on both legal and physical persons of the EC as a prerequisite for their adherence set unnecessary obstacles to the EC growth of its membership base, while leaving out various potential members. Such rules also raise questions on their compliance with the open-door principle as stated in ICA and prescribed in PECOL ${ }^{65}$, as well as with the constitutionally established self-governance of the cooperatives in ar. 12.4 of the Greek Constitution.

Furthermore, the allocation of surpluses in the EC seems rather problematic before as well as after their dissolution/liquidation, since the distinctive financial structure of cooperatives and in particular the different function of surpluses and profits in the cooperative is not being taken properly into account. In particular, the legislator seems to polarize the institution of the EC by implicitly dividing it into the not-for-profit and for-profit EC. The former resembles in some of their attributed traits the general interest cooperatives which pursue mainly the common good of the community, such as by introducing an absolute clause of reserves' indivisibility and the latter EC seem closely associated with the investor owned model of enterprise, as they are permitted to allocate all the surpluses as well as their remainder after dissolution/liquidation to their members. Nevertheless, a middle ground solution of the EC functioning as a cooperative with a mutual purpose, providing part of its surpluses as patronage refunds to its members based on their cooperative transactions and in the event of its dissolution allocating the remainder to other cooperatives is not foreseen by the provisions of L. 4513/2018.

Overall, the new law on energy communities is added to the plethora of cooperative specific laws, further fragmenting the legal landscape of Greek cooperatives. Nevertheless, it introduces some positive traits to the EC, and from this aspect it may be viewed as a positive step forward. However, several provisions seem rather inconsistent with the cooperative values and principles and need to be re-examined, so that the new law may reach its full potential and contribute to the country's transition to the green energy and energy democracy.

\section{BIBLIOGRAPHY}

ATANASIOU, B., KONTONASIOU, E., MARIOTTINI, F., Alleviating fuel poverty in the EU: Investing in home renovation, a sustainable and inclusive solution, Buildings Performance Institute Europe (BPIE), 2014.

AVDELIDIS, P., The agricultural cooperative movement in Greece (in Greek), $2^{\text {nd }}$ ed., Athens, Papazisi Editions, 1976.

\footnotetext{
${ }^{65}$ Sec 1.3 (6) PECOL: "Cooperative statutes may make membership subject to reasonable conditions related to their particular type or objective, without gender, social, ethnic, racial, political or religious discrimination or artificial restriction of membership".
} 
BELLIS, V., The case of the Energy cooperative company of Karditsa, Korinthos Chambers, 18th of February 2018.

DAGTOGLOU, P., Constitutional Law - Civil rights, Athens, Ant. N. Sakkoulas, 2005.

DOUVITSA, I. The provisions on the company name of cooperatives according to cooperative legislation- in Greek, Editors' Newspaper, 30th of July 2018.

DOUVITSA, I. «Supervision and audit of the Greek agricultural cooperatives: A critical approach on legislation», European Business Law Review 29 (2018).

DOUVITSA, I., «National constitutions and cooperatives. An overview», International Journal of Cooperative Law 1 (2018).

Explanatory report of draft law "Energy communities and other provisions", $14^{\text {th }}$ of November 2017.

FAJARDO GARCIA, I.G., Spain in: Cracogna, D., Fici, A., Henrÿ (eds), H. International handbook of cooperative law, Heidelberg, Springer, 2013.

FAJARDO, G., FICI, A., HENRŸ, H., HIEZ, D., MEIRA, M., MUNKNER, HH., SNAITH, I., Principles of European Cooperative Law. Principles, Commentaries and National Reports, Cambridge, Intersentia, 2017.

FAJARDO, G., The European legal framework, does it promote renewable energy selfconsumption cooperatives?, International Cooperative Alliance (ICA) European Research Conference "Cooperatives in a rapidly changing world: Innovation in Enterprise and Community", 4 July 2018 until Fri 6 July 2018, Wageningen, Netherlands.

FJøRTOFT, T., GJEMS-ONSTAD, O, Norway and Scandinavian countries, in: Cracogna, D., Fici, A., Henrÿ, H. (eds), International handbook of cooperative law, Heidelberg, Springer, 2013.

HENRŸ, H., Guidelines for Cooperative Legislation, $3^{\text {rd }}$ ed., Geneva, International Labour Organization, 2012.

HENRŸ, H., Public International Cooperative Law, in Cracogna, D., Fici, A., Henrÿ, H. (eds), International handbook of cooperative law, Heidelberg, Springer, 2013.

HENRŸ, H., Finland, in: Fajardo, G., Fici, A., Henrÿ, H., Hiez, D., Meira, M., Munkner, HH., Snaith, I., Principles of European Cooperative Law. Principles, Commentaries and National Reports, Cambridge, Intersentia, 2017.

ILIOPOULOS, C., VALENTINOV, V., «Opportunism in Agricultural Cooperatives in Greece». Agriculture 41 (2012).

International Cooperative Alliance, Guidance notes to the co-operative principles, 2015.

International Labour Office (ILO), Cooperatives Unit (ENT/ COOP), Green Jobs Program., Providing clean energy and energy access through cooperatives, Geneva, ILO, 2013

JONES, S., Social causes and consequences of energy poverty, in Csiba, K., Bajomi, A., Gosztonyi, A., Energy poverty handbook, Brussels, European Union, 2016.

KAMINARI, O., PAPAGEORGIOU, K., «The concept of surpluses, profits and net income in cooperatives in Greek», Social Economy, April's Volume, Athens, Institute for Cooperative Studies, 2016.

KASSAVETIS, D., Cooperative Institutions I. Agricultural Cooperative Organizations (in Greek), Athens, Katsarou, 2005.

KINTIS, S., Cooperative Law (in Greek), Athens, Ant. N. Sakkoulas, 2004. 
KLIMI-KAMINARI, O., PAPAGEORGIOU, K., Social economy: A first approach (in Greek), Athens, Ellinoekdotiki, 2010.

KLIMI-KAMINARI, O., The relations between state and cooperatives in Greece for the development of the agricultural population (in Greek), Athens, Panteion University of Social and Political Sciences, 2003.

LAMBROPOULOU-DEMETRIADOU, B., Assessment of the Greek Cooperative Legislation, in Papageorgiou, K., (ed.), An Assessment of Greek Cooperative Institutions (in Greek), Athens, Institute of Cooperation, 1995.

MAVROGIANNIS, D. Sociology of Law Courses: University lectures (in Greek), Athens, Sakkoulas, 1980.

MAVROGIANNIS, D., The Social Right of Cooperatives, in Five Years of Implementation of the Constitution of 1975 (in Greek), Komotini, DUTH, 1981.

MEIRA, D., Legal obstacles to the creation of renewable energy communities under cooperative form in Portugal: Coopernico as a case study, International Cooperative Alliance (ICA) European Research Conference "Cooperatives in a rapidly changing world: Innovation in Enterprise and Community”, 4 July 2018 until Fri 6 July 2018, Wageningen, Netherlands.

MEIRA, D., Portugal, in: Fajardo, G., Fici, A., Henrÿ, H., Hiez, D., Meira, M., Munkner, HH., Snaith, I., Principles of European Cooperative Law. Principles, Commentaries and National Reports, Cambridge, Intersentia, 2017.

MUNKNER, HH., Germany, in: Cracogna, D., Fici, A., Henrÿ, H. (eds), International handbook of cooperative law, Heidelberg, Springer, 2013.

PANAS, E., Research on energy poverty in Greece in Greek, Department of Statistics, Athens University of Economics and Business, 2012.

PATRONIS, V., MAVREAS, K., «Agricultural cooperative organizations in Greece throughout the 20th Century: A Critical Overview», Journal of Rural Cooperation 32 (2004).

Public Consultation Report for the draft law "energy communities and other provisions", July 2017, Hellenic Democracy, Ministry of Environment and energy.

ROELANTS, B. Capital building in industrial and service cooperatives, in: The capital conundrum for cooperatives, 2016, International Co-operative Alliance.

SANTAMOURIS, M., PARAVANTIS, JA., FOUNDA, D., «Financial crisis and energy consumption: a household survey in Greece», Energy and Buildings 65 (2013).

SNAITH, I. (2013). United Kingdom, in: Cracogna, D., Fici, A., Henrÿ, H. (eds), International handbook of cooperative law, Heidelberg, Springer.

SOTIROPOULOS, D., CHRISTOPOULOS, L., Overregulation and bad quality laws in Greece, Athens, Dianeosis, 2017.

THOMSON, HR, SNELL, C.J., "Quantifying the prevalence of fuel poverty across the European Union», Energy policy 52 (2013).

XRYSOGONOS, K., Civil and Social Rights (in Greek), Athens, Nomiki Vivliothiki, 2006. 